\title{
ENGLISH INTERDENTAL FRICATIVE PRODUCTION IN DUTCH HERITAGE SPEAKERS LIVING IN CANADA
}

\author{
Sarah Cornwell ${ }^{*}$ \\ The University of Western Ontario, CAN \\ Yasaman Rafat ${ }^{* *}$ \\ The University of Western Ontario, CAN
}

\begin{abstract}
This study investigates the production of $/ \theta /$ and /ð/ by three groups of English-speakers in the community of Norwich, Ontario, Canada. English monolinguals, heritage Dutch speakers (early bilinguals), and L1 Dutch/ L2 English speakers (late-learning bilinguals) $/ \theta /$ and $/ ð /$ production was measured in both naturalistic and reading tasks. Heritage Dutch speakers produce $[\theta]$ and $[ð]$ at similar rates to Monolingual English speakers, but the two groups exhibit different allophonic realizations, especially when /ð/ is word-initial and $/ \theta /$ is word-medial. This study suggests that despite their ability to produce $[\theta]$ and $[ð]$, Dutch heritage speakers may manipulate the inherently variable English $/ \theta$ / and / / production to communicate their Dutch cultural identity. This is the first study to examine both heritage Dutch bilinguals in Canada and non-English as a Foreign Language (EFL) classroom Dutch English.
\end{abstract}

Keywords: Heritage phonology; Bilingualism; L2 speech learning; Socio-phonetics; Interdental fricatives; Dutch; English

\subsection{Introduction}

This study aims to add to the body of literature on heritage speakers' phonology by examining how heritage Dutch speakers' English $[\theta]$ and [ð] production may differ from both 'typical' late L2 learners and native speakers of English. In particular, the purpose of this study is to examine both the type and rate of L1-based phonological transfer. Transfer in this case is the way in which Dutch phonology may affect the acquisition, and specifically the production, of English. Although more work has been done on L2 production (e.g. Best and Tyler (2007); Colantoni and
Steele (2008); Flege (1995)), there is a growing body of literature on heritage-speaker phonology (Hoffman \& Walker, 2010; Chang, Yao, Haynes, \& Rhodes, 2011; Rao \& Kuder, 2016).

Dutch has no $[\theta]$ and $[ð]$ in its phonology, and research has shown that even highly proficient speakers often produce these sounds in English in a non-targetlike manner (Schmid, Gilbers, \& Nota, 2014; Wester, Gilbers, \& Lowie, 2007). The literature on Dutch L1 English learners has mainly focused on L2 speakers who acquired English in an English as a Foreign Language

\footnotetext{
Graduate of the Masters of Arts in Linguistics program at the University of Western Ontario, and is a doctoral candidate for Library and Information Science at the same institution. Her research interests are in language acquisition, sociolinguistics, and text analytics. Her e-mail address is scornwel@uwo.ca

Assistant professor in the Department of Modern Languages and Literatures at the University of Western Ontario. She holds a PhD in Hispanic studies from the University of Toronto. Her work has focused on second language speech learning. She is primarily interested in the effects of auditory-orthographic interaction and integration in bilinguals. She has also worked on speech production, processing and dialectal acquisition and change bilinguals. Her e-mail address is yrafat@
} uwo.ca 
(EFL) context and little is known about learners who learn English outside of an EFL classroom. Moreover, most studies on immigrant Dutch bilinguals have focused on attrition of Dutch, rather than the acquisition of English (c.f., Crezee (2012); Hulsen (2000); Hulsen, de Bot, and Weltens (2002)). The township of Norwich, Ontario, provides an opportunity to study the English of Dutch bilingual immigrants and heritage speakers, as $9.2 \%$ of the population reports Dutch as their mother tongue (Statistics Canada, 2012), and approximately $20 \%$ of residents are of Dutch descent (Schryer, 1998, p. 75). The research in this study will focus on these two population groups and attempt to answer the following questions:

1. Do heritage speakers of Dutch differ from monolingual English speakers and late-learning L1 Dutch L2 English bilinguals in their realization of $[\theta]$ and $[ð]$ ?

2. Is Dutch heritage speakers' $[\theta]$ and $[ð]$ production more similar to those of the late-learning L1 Dutch bilinguals or monolingual English speakers?

\subsection{Literature Review}

\subsection{Dutch Presence in Canada}

Studies of immigrant language use suggest that Dutch immigrants tend to assimilate quickly in Anglophone societies (Harrison, 2000; Hulsen, 2000). As a result, previous studies on Dutch immigrants and their descendants have largely focussed on the attrition of their L1, rather than their acquisition of English. In Canada, 34\% of the Dutch immigrant population married someone whose native language is English or French, and only 1\% taught Dutch to their children as a first language (Harrison, 2000). Only 25\% of Ontarians who speak Dutch as a mother tongue continue to speak Dutch in the home (Schryer, 1998, p. 163). VanDijk notes that while Dutch Calvinists (like many in Norwich ) are more likely to resist language assimilation in comparison to Dutch Catholics or those of other religions, Calvinist rates of Dutch language use are only marginally higher than other groups (2007). The overall high degree of language assimilation may result in Heritage speakers producing $[\theta]$ and $[\partial]$ in a manner more similar to their English monolingual peers than to late-learning Dutch L1 speakers.

\subsection{L1 Dutch L2 English Phonology}

In general, L1 Dutch/L2 English speakers can attain a high degree of fluency in English. Schmid et al. (2014) found that high-fluency Dutch L2 English speakers did not differ significantly from English speakers on c-test fluency tasks. However, L1 Dutch speakers' speech is still recognizably accented, in both vowel (Schmid et al., 2014) and interdental fricative production (Wester et al., 2007). Wester et al. (2007) looked at the realizations of $[\theta]$ and $[ð]$ in naturalistic English speech by highly fluent L1 Dutch/L2 English speakers. They found that $[\theta]$ and $[ð]$ were most commonly realized as $[t]$ and $[d]$ in word-initial position and as $[\mathrm{s}]$ and $[\mathrm{z}]$ in word-final position. These realizations follow a different pattern than those of English L1 $[\theta]$ acquisition, which tends to favour [f] (Wester et al., 2007). Wester et al. (2007) attribute this to $[\mathrm{t}]$ and $[\mathrm{d}]$ being more unmarked sounds (they have fewer features that differentiate them from $[\theta]$ and $[ð]$ in Dutch phonology). L1 Dutch/ L2 English speakers also confuse $[\theta]$ and $[ð]$ perceptually, commonly confusing $[\theta]$ for $[\mathrm{f}]$ and $[\mathrm{s}]$ and [ð] for [d], [z], and [s] (Cutler, Weber, Smits, \& Cooper, 2004). These patterns of $[ð]$ and $[\theta]$ production and perceptual confusion suggest that we will find some of these patterns of variable $[\theta]$ and [ð] production in Norwich's late learning L1Dutch/ L2English bilinguals and Dutch heritage speakers.

\subsection{Heritage Phonology}

Chang et al.,(2011) compared the production of similar (but distinct) Mandarin and English vowels, plosives, and fricatives by four different groups: native Mandarin speakers, heritage Mandarin speakers with low and high Mandarin exposure, and late Mandarin learners/English native speakers. Of the four groups, 
both heritage speaker groups produced the similar phonemes with stronger between-language contrasts than the late-learning groups. The heritage groups also maintained strong within-language contrasts. Chang et al. (2011) use Flege's Speech Learning Model (SLM) to explain this. According to the SLM, learners acquire the phonology of their second language by creating contrasting categories for sounds, which are highly dissimilar to those in their native language (new sounds), but they tend to merge similar sounds with categories for their native language. This merger is more likely to occur as the age of acquisition increases. That is, late learners will be more likely to merge similar sounds. Heritage speakers acquire the sounds of both languages simultaneously and at a young age, so they are more likely to create more distinct and accurate between-language contrasts. As a result, they tend to produce native-like sounds for both of their languages, outperforming late-learners.

Hoffman and Walker (2010) investigated the ethnolects of Chinese and Italian heritage speakers in Toronto. Their findings suggest that differences between monolingual's English and heritage speakers' English are due to group identity rather than learning L2 speech patterns from their parents. Gatbonton, Trofimovich, and Segalowitz (2011) found similar ethnic-identity effects for French L1 English speakers' /ð/ production. L2 speakers who viewed French language maintenance as an important political statement produced significantly less [ð] in their English productions, even when accounting for English proficiency. In their wideranging survey of UK immigrants' intergenerational language use, Parameshwaran (2013) found that while the ethnic or heritage language underwent attrition over successive generations, English (majority language) proficiency was generally native-like for all people raised in the UK. Among Heritage groups, a positive attitude towards assimilation correlated with higher levels of English fluency. Calvinist Dutch Heritage speaker communities have a strong sense of Dutch identity, but they generally prefer to speak English (Van Dijk, 1998). This suggests that while the Dutch community in Norwich has largely linguistically assimilated to the English-language majority, they maintain a strong Dutch identity. These studies suggest that heritage speakers with stronger cultural ties to the Dutch community may exhibit some "Dutch-like" features in their production of English, or may show some transfer from their Dutch for this reason.

As a counterpoint, there are rare examples of ethnic or ethno-religious identity affecting majority language use even in monolingual English speakers. A North American example of this is the Pennsylvania Dutch Anabaptists (Downing, 2015; Huffines, 1980; Parker, 1991). This group is comprised of ethnically German Old-Order Amish and Mennonite populations living not just in Pennsylvania, but also in Ohio and Southern Ontario. Despite the first migrants arriving in the late nineteenth century, these populations have maintained a dialect of heritage German that exists today (Huffines, 1980). While the majority of young people in these communities are monolingual English speakers (Huffines, 1980), these speakers still "exhibit a large influence of the Pennsylvania German dialect in their speech" (Parker, 1991, p. 23). This influence differentiates the English of the Pennsylvania Dutch from the majority English of the United States (Parker, 1991). Consonantal features include / $/$ / stopping, the realization of $/ \theta /$ as $[s]$, and final obstruent devoicing (Downing, 2015; Huffines, 1980). While these features are similar to German L1 English speakers, Pennsylvania Dutch Anabaptists are largely monolingual English speakers, so L2 theories (like the SLM) cannot be used to describe their speech. Instead, Parker (1991) explains that these English productions are a method of labelling themselves as a member of the Anabaptist community, and therefore, excluding themselves from secular English American culture. While the Dutch Calvinist community in Norwich is not as insular as the Anabaptists, Schryer (1998) notes that the Orthodox Calvinist church in Norwich is one of the two most conservative and insular Dutch church sects in Ontario (the other is in Ancaster). This insularity has resulted in strong social networks that may help to explain the survival of Dutch English features in Norwich Township heritage speakers. This means we may find an increased rate of typical Dutch L1 features in heritage English production. In the context of this study, this 
could be seen as an increased rate of [d] production as an allophone of $/ \delta /$, and [t] and $[s]$ as allophones of $/ \theta /$.

\subsection{Monolingual production of the English Interdental Fricative}

Flege, Munro, and MacKay (1995) measured the word-initial production of English $/ \theta /$ and $/ \partial /$ by Canadian English monolinguals, and Italian L1 English speakers who began acquiring English at different ages. They found that both the monolinguals and Italian L1 who acquired English at or before age 8 produced $[\theta]$ and $[ð]$ in approximately $70 \%$ of tokens. Those who acquired English later in life produced both sounds at lower rates - speakers who acquired English as adults only produced $[\theta]$ and $[ð]$ in $20 \%$ of tokens. Speakers who acquired English at or before age 8 (both monolinguals and Italian L1) realized $/ \theta /$ as $[\mathrm{t}]$ and $/ \partial /$ as [d] in the majority of the remaining tokens (Flege et al., 1995). This study shows us that $/ \theta /$ and $/ \delta /$ production is variable even within monolingual English speakers.

Zhao (2010) investigated /ð/ production and also found that English monolinguals did not produce [ð] as a fricative in $100 \%$ of /ð/ target tokens. [ð] was sometimes realized as "stop-like $\partial$ ", especially after a pause, vowel, liquid, or fricative. "Stop-like $\partial$ " is different from [d], having a significantly higher burst spectrum peak and mean spectral frequency, as well as a significantly weaker and flatter spectral burst shape. Roach even goes so far as to deny that $/ \theta /$ and $/ \partial /$ are fricatives, preferring to describe them as "weak dental plosives" (2010, p. 56). The high degree of similarity between monolingual English production of /d/ and /ð/ suggests that these sounds could be merged in L2 English phonologies under Flege's SLM.

$/ \theta /$ and $/ ð /$ are not present in all English dialects or discriminated by all native English speakers (Munro \& Derwing, 2006). $/ \theta /$ and $/ \partial /$ have been found to be supplanted by /d/ and / $\mathrm{t} /$ in Newfoundland by Boberg (2010), in AAVE by Labov (cited in Gatbonton et al. (2011)), New York City by Best and Tyler (2007) and in Belfast by Milroy (cited in Gatbonton et al. (2011)). $/ \theta /$ has also been frequently supplanted by /f/ in many British (Blevins, 2004; Hanulikova \& Weber, 2012),
Australian, and New Zealand dialects (Jekiel, 2012) as well as word-finally and inter-vocalically by AAVE speakers (Jekiel, 2012). / $\theta$ / is also frequently confused by English monolingual children - the $[\theta]$ - [f] contrast is one of the few English consonant contrasts that infants struggle to discriminate (Vihman, 1996 in Blevins (2004)). The interdental fricatives are some of the last sounds to be acquired by North American English speaking children (Bernhardt \& Stemberger, 2002). In General American English, $/ \theta /$ is usually acquired around age 6 , while / $/$ / is acquired around age 7 (Smith, 2007). Prior to that age, it is common for / $/ \mathrm{d}$ to be produced as [d] and for $/ \theta /$ to be produced as [f] or [s] (Smith, 2007). The minimal contrastive function of $/ \theta /$ and $/ ð /$ allows these sounds to be produced variably by English speakers of many different dialects.

\subsection{Hypotheses}

It is predicted that:

1. The three groups will differ and fall along a continuum, with English speakers producing the highest rate of $[\theta]$ and $[ð]$. Late bilingual Dutch immigrants will experience some transfer from their L1, and so will produce the lowest rate of $[\theta]$ and [ð] (as in Wester et al., 2007). Heritage speakers will produce $[\theta]$ and $[ð]$ at a rate close to, but lower than the English monolingual speakers (following findings by Chang et al. (2011); Hoffman and Walker (2010)).

2. All three groups will exhibit allophonic variation for $[\theta]$ and $[ð]$ production. However, the patterns of allophonic distribution will differ between the three groups. The Dutch heritage speakers' patterns of $[\theta]$ and $[ð]$ allophonic production will be similar to those of the Dutch L1 speakers as reported in Wester et al. (2007). Specifically, they will tend to produce $[\mathrm{d}]$ and $[\mathrm{t}]$ as allophones at a significantly higher rate than the $[\mathrm{s}]$ and $\varnothing$ (zero) allophones which characterize monolingual English speakers. 


\subsection{Method}

\subsection{Participants}

21 participants were recruited for this study. The participants were between age 20-80, with a mean age of 49. The participants were divided into three groups (L1 Dutch/ L2 English bilinguals, heritage Dutch bilinguals, English monolinguals) according to their responses to the Dutch and English fluency portions of the proficiency questionnaire task. All of the participants were recruited from the Township of Norwich, Ontario, Canada. Two of the English monolingual group members were not raised in Norwich, but were raised in other Southwestern Ontario communities.. Table 1 shows the demographic data of the participants (see Appendix A for a detailed participant table). and who learned English as adults were put in the 'L1 Dutch/L2 English' group. Participants who spoke both languages but learned English as children, who prefer English, and who rank their Dutch fluency as equal to or less than their English fluency were put in the 'Heritage' group. The 'English' group consists of self-reported English monolinguals. Due to being educated in Canada, a few English participants reported low proficiency in French. A copy of the LEAP-Q is included in Appendix B.

The second task was a naturalistic production task. The participants were audio-recorded as they completed a picture description task. The participants were asked to describe each of the pictures in detail, "as if [they were] describing it to someone who was attempting to draw it". They viewed each of the 3 pictures as they were presented one-by-one on a computer screen. The task was self-paced, and took participants a mean of 3

\begin{tabular}{|l|l|l|l|l|l|l|}
\hline Group & $\begin{array}{l}\text { Average } \\
\text { Age }\end{array}$ & Gender & $\begin{array}{l}\text { Average Edu- } \\
\text { cation (years) }\end{array}$ & $\begin{array}{l}\text { Average Age of } \\
\text { Immigration }\end{array}$ & $\begin{array}{l}\text { Average } \\
\text { Dutch } \\
\text { Fluency }\end{array}$ & $\begin{array}{l}\text { Average } \\
\text { English } \\
\text { Fluency }\end{array}$ \\
\hline $\begin{array}{l}\text { L1 Dutch/ L2 } \\
\text { English }\end{array}$ & 57 & $\begin{array}{l}\text { Female: } 2 \\
\text { Male: } 7\end{array}$ & 11 & 21 & 9.4 & 8.6 \\
\hline Heritage & 34 & $\begin{array}{l}\text { Female: } 4 \\
\text { Male: } 2\end{array}$ & 16 & 5 & 7.7 & 10 \\
\hline English & 51 & $\begin{array}{l}\text { Female: } 4 \\
\text { Male: } 2\end{array}$ & 17.5 & $\mathrm{n} / \mathrm{a}$ & $\mathrm{n} / \mathrm{a}$ & 10 \\
\hline $\begin{array}{l}\text { TOTAL / } \\
\text { AVERAGE }\end{array}$ & $\mathbf{4 9}$ & $\begin{array}{l}\text { Female: } \mathbf{1 0} \\
\text { Male: } \mathbf{1 1}\end{array}$ & $\mathbf{1 4 . 5}$ & & & \\
\hline
\end{tabular}

Table 1: A summary of the participants' demographic data. 4.2 Tasks

The experiment consisted of three production tasks. First, all participants were required to complete the Language Experience And Proficiency Questionnaire (LEAP-Q) (adapted from Marian, Blumenfeld, and Kaushanskaya (2007)). This survey asks about basic demographic information and relative experience and proficiency with both English and Dutch. The results of the LEAP-Q were used to sort the participants into groups based on the ages at which they learned Dutch and English, and their relative language proficiencies. Participants who preferred Dutch, ranked their Dutch fluency as equal to or greater than their English fluency, minutes to complete. This task was designed to elicit natural production.

The third task was a reading task. All of the participants were audio-recorded as they read aloud a paragraph that contains target $/ \theta /$ and $/ \partial /$ words. The task was self-paced, and took less than 2 minutes for participants to complete. This task ensured that there were at least 5 tokens from 5 unique words demonstrating each position (initial, medial, and final) and each sound $(/ \theta /$ and $/ \delta /)$ from each participant.

\subsection{Stimuli}

In the naturalistic production task, one picture contained details designed to elicit 31 words containing 
$/ \theta /$ and $/ ð /$ (seeAppendix C). Due to the naturalistic nature of this task, all 31 words were not produced by each participant. More balanced data was recorded from the reading task. The reading task paragraph contained 31 target words for /ð/: 21 word-initially (i.e., though /ðо/), 5 word-medially (i.e., lather /læðəı/), and 5 word-finally (i.e., bathe /beð/). It also contained 31 target words for $/ \theta /$ : see Appendix D.

\subsection{Data Analysis}

The tokens were auditorily transcribed and coded by the English-native author working in Praat for Mac v5.4 (Boersma, 2013). Each token was labeled as either $[\theta],[ð],[t],[d],[s], \varnothing$ (zero), or other. A spectrogram produced by Praat was used to confirm segment labeling. Specifically, short duration productions of /ð/ were checked for evidence of "gaps" that would indicate a closure ([d]). A multiple regression analysis was done in Rbrul (Johnson, 2009) to determine which factors significantly affected $[\theta]$ and $[ð]$ production rates and patterns of allophone realization. The factor variables included in the analysis were: group (English, Heritage, L1 Dutch/L2 English), task (picture description, reading), gender (male, female), and position in the word (initial, medial, final). Two continuous variables were also included: age and word frequency. Word frequency was calculated using the logarithmic frequency from the SUBTLEXus database (Brysbaert \& New, 2009) as accessed through the English Lexicon Project's website (Balota et al., 2007). Individual speakers were accounted for as a random effect to prevent any one participant from having possible outlier effects.

\subsection{Results}

\subsection{Voiced Interdental Fricative}

A mixed-effect variable rule statistical analysis done in Rbrul showed that / $/$ / production varied significantly due to group affiliation $(\mathrm{p}<0.001)$, position in the word $(\mathrm{p}<0.001)$ and task $(\mathrm{p}<0.05)$. The log-odds table is shown in Table 2. Gender, age, and word frequency were not significant predictors of $/ \partial /$ production. No interactions between variables were found. The results of each task are discussed separately below.

\begin{tabular}{|c|c|c|c|}
\hline Input Probability & \multicolumn{3}{|l|}{0.479} \\
\hline Total N & \multicolumn{3}{|l|}{1634} \\
\hline Deviance & \multicolumn{3}{|l|}{1621.391} \\
\hline $\begin{array}{l}\text { Degrees of } \\
\text { freedom }\end{array}$ & \multicolumn{3}{|l|}{7} \\
\hline Factor & Log-odds ${ }^{1}$ & Tokens & Percentage [ð] \\
\hline Group & \multicolumn{3}{|l|}{$\mathrm{p}<0.001$} \\
\hline English & 1.332 & 708 & 80.5 \\
\hline Heritage & 0.336 & 425 & 58.6 \\
\hline $\begin{array}{l}\text { L1 Dutch / } \\
\text { L2 English }\end{array}$ & -1.668 & 501 & 17.6 \\
\hline Location & \multicolumn{3}{|l|}{$\mathrm{p}<0.001$} \\
\hline Word medial & 0.353 & 163 & 53.4 \\
\hline Word initial & 0.072 & 1367 & 57.4 \\
\hline Word final & -0.425 & 104 & 33.7 \\
\hline Task & \multicolumn{3}{|l|}{$\mathrm{p}<0.05$} \\
\hline $\begin{array}{l}\text { Picture } \\
\text { Description }\end{array}$ & 0.278 & 954 & 65.8 \\
\hline Reading & -0.278 & 680 & 41.0 \\
\hline
\end{tabular}

Table 2: Result of the mixed effect statistical analyses for production of /ð/ words

\subsubsection{Picture Description Task}

The participants produced an average of $45 / ð /$ tokens across a total of 38 unique /ð/ words. English monolinguals produced the highest number of tokens (51.8\% of all tokens), which was especially due to two speakers who spoke for 8 and 9 minutes and produced over 180 tokens each. The average token count for the English group with these speakers removed remained higher than the other two groups at 66.5 tokens. The full breakdown of both $/ \partial /$ and $/ \theta /$ token counts and the number of unique words used by each group is presented inTable 3 . 


\begin{tabular}{|c|c|c|c|c|}
\hline Group & $\begin{array}{l}\text { L1 Dutch / L2 } \\
\text { English }\end{array}$ & Heritage & English & Total \\
\hline Average Task Duration: m:ss & $2: 12$ & $2: 52$ & $5: 24$ & $3: 18$ \\
\hline Average tokens/speaker (st.dev) & $31.1(17.0)$ & $51(31.1)$ & $105.5(65.4)$ & $58.0(49.4)$ \\
\hline$\%$ total $/ \theta /$ tokens $(\mathrm{n})$ & $27.3 \%(73)$ & $27.3 \%(73)$ & $45.3 \%(121)$ & $100 \%(267)$ \\
\hline$\%$ total /ð/ tokens $(\mathrm{n})$ & $21.8 \%(207)$ & $24.5 \%(233)$ & $53.7 \%(511)$ & $100 \%(951)$ \\
\hline$\%$ total $/ \theta /$ and $/ ð /$ tokens $(\mathrm{n})$ & $23.0 \%(280)$ & $25.1 \%(306)$ & $51.8 \%(632)$ & $100 \%(1219)$ \\
\hline$\%$ unique $/ \theta /$ word $(\mathrm{n})$ & $54.8 \%(17)$ & $58.1 \%(18)$ & $74.2 \%(23)$ & $100 \%(31)$ \\
\hline$\%$ unique / / / word (n) & $58.8 \%(20)$ & $52.9 \%(18)$ & $94.1 \%(32)$ & $100 \%(34)$ \\
\hline$\%$ of all unique words (n) & $56.9 \%(37)$ & $55.4 \%(36)$ & $84.6 \%(55)$ & $100 \%(65)$ \\
\hline
\end{tabular}

Table 3: Tokens and unique words produced in the picture description task

The most between-group variability was observed at the word-initial position of /ठ/. The groups' production was significantly different from one another $(\mathrm{p}<0.001)$. $/ ð /$ also had the most numerous tokens $(\mathrm{n}=893)$ due to the high proportion of word-initial /ð/ function words in English. English monolinguals produced /ð/ as [ð] in $85 \%$ of tokens $(n=484)$. The remaining tokens were realized as $\emptyset(9 \%),[\theta]$ (3\%), and [d] (2\%). The L1 Dutch/ L2 English group produced [d] at $60 \%$ usage, while also producing [ð] in $20 \%$ of tokens. The remaining $20 \%$ were produced as $\varnothing(n=191)$. The Heritage group's rate of [ð] production was between the other two groups, with [ð] produced in $62 \%$ of tokens $(n=218)$. Similar to the L1 Dutch / L2 English group, the Heritage group produced [d] as the most common allophone of $/ \partial /$, producing [d] in $25 \%$ of tokens. The remaining productions were more similar to the English group, with $12 \%$ of the tokens realized as $\varnothing$, and the remaining $1 \%$ as $[\theta]$.

The three groups produced a total of 58 medial /ð/ tokens across 16 unique words. Both the English and Heritage groups produced [ð] very consistently at this position. The English group produced $92.9 \%$ tokens as [ð], $3.6 \%$ as $[\theta]$, and $3.6 \%$ as $\varnothing(\mathrm{n}=28)$. The Heritage group produced 15 tokens, of which $93.3 \%$ were [ð] and $6.7 \%$ were [d]. The L1 Dutch/ L2 English group produced $81.3 \%$ [d] and $18.8 \%$ [ð] $(\mathrm{n}=16)$. Only a single /ð/ token was recorded in the word-final position for this task - an English monolingual production of $[ð]$ in "bathe".

\subsubsection{Reading Task}

The task effect for $/ ð /$ shows a tendency for all three groups to produce more varied realizations of $/ \partial /$ in the reading task. Word-initially, the /ð/ reading task results were very similar to those of the picture description task, though overall the groups produced a lower proportion of [ð] tokens. The English group produced the most [ð] at $73 \%$. The remaining realizations were $\varnothing(12 \%),[\theta]$ $(12 \%)$, and [d] (3\%). The Heritage group produced less [ð] (54\%) and unlike the English group, favoured [d] (21\%). The remaining tokens were very similar to the English group and were split between $\varnothing(15 \%)$ and $[\theta]$ (10\%). The L1 Dutch/ L2 English group successfully produced [ð] in only $15 \%$ of tokens at this position, instead producing $[\mathrm{d}]$ in the majority of tokens $(63 \%)$. The remaining tokens were $\varnothing(15 \%),[\theta]$ (3\%), [t] (1\%), and other (2\%).

Word-medial /ð/ words showed more variation than in the picture description task. The English and Heritage groups both produced a majority of tokens as [ð]. These two groups produced a similar pattern of allophonic variation - using $[\theta],[d]$, and $\varnothing$ at similar rates, though the Heritage group produced more [d] than the English group. The L1 Dutch/ L2 English group produced $[\mathrm{d}]$ in the majority of tokens (58\%), but also produced [ð], $[\theta],[d],[s], \varnothing$, and others.

The standard $[\varnothing]$ production was low in all three groups in final position. The English and Heritage groups both produced [ð] in about $45 \%$ of tokens. The English group frequently devoiced [ð] in this position, 
producing $[\theta]$ in $43 \%$ of tokens. English monolinguals also rarely produced [s] (7\%) and [d] (3\%). The Heritage group also produced $[\theta]$, but at a lower rate $(30 \%)$. This group realized $/ ð /$ as $[\mathrm{d}]$ at the highest rate of all three groups (26\%). The L1 Dutch / L2 English group was again more variable than the other two groups, and produced $[\theta]$ in the largest number of tokens $(42 \%)$. The L1 Dutch/ L2 English group produced [ð] in 24\% of cases, while also substituting with [d] (18\%), [s] (8\%), and other sounds (8\%).

\subsection{Voiceless Interdental Fricative}

A mixed effect variable rule statistical analysis done in Rbrul showed that $/ \theta /$ production varied significantly as a result of group affiliation $(p<0.01)$ and position in the word $(\mathrm{p}<0.01)$. The log-odds table is shown in Table 4. Task, gender, age, and word frequency were tested for, but were not significant factors. There were no significant interaction effects. There was not a significant task effect for $/ \theta /$ production, so the position and group data presented in this section represent the results for both tasks. Overall, all three groups exhibited a tendency to produce $/ \theta /$ as $[\theta]$. This sound was produced with greater accuracy and with less allophonic variation than /ð/.

\begin{tabular}{|c|c|c|c|}
\hline Input Probability & \multicolumn{3}{|l|}{0.764} \\
\hline Total N & \multicolumn{3}{|l|}{914} \\
\hline Deviance & \multicolumn{3}{|l|}{765.864} \\
\hline Degrees of freedom & \multicolumn{3}{|l|}{6} \\
\hline Factor & Log-odds & Tokens & $\begin{array}{l}\text { Percentage } \\
{[\theta]}\end{array}$ \\
\hline Group & \multicolumn{3}{|l|}{$\mathrm{p}<0.01$} \\
\hline English & 0.977 & 306 & 87.9 \\
\hline Heritage & 0.593 & 255 & 82.7 \\
\hline L1 Dutch/ L2 English & -1.569 & 353 & 46.7 \\
\hline Location & \multicolumn{3}{|l|}{$\mathrm{p}<0.01$} \\
\hline Initial & 0.408 & 365 & 74.0 \\
\hline Medial & -0.127 & 151 & 68.2 \\
\hline Final & -0.280 & 398 & 68.3 \\
\hline
\end{tabular}

Table 4:The results of the mixed effects statistical analysis for $/ \theta /$ production
Word-initially, all three groups produced $[\theta]$ in the majority of tokens. The Heritage group $(n=97)$ and English group $(\mathrm{n}=114)$ both produced $[\theta]$ very regularly, producing $[\theta]$ in over $87 \%$ of tokens. The L1 Dutch/ L2 English group produced $[\theta]$ in $53 \%$ of tokens $(n=155)$. The most common allophone of $/ \theta /$ for the Heritage and English groups was [s]. [s] occurred in approximately 6\% of both groups' tokens. The L1 Dutch/ L2 English group also produced $[\mathrm{s}]$ in $9 \%$ of tokens, but preferred to substitute with [t], which was found in $31 \%$ of tokens. The Heritage group also produced [ $\mathrm{t}$ ] as a realization of $/ \theta /$, but more infrequently than the L1 Dutch/ L2 English group (5\%). The English group produced both [t] and [ð] extremely rarely, in only 1 token each $(<1 \%)$.

The three groups also produced $[\theta]$ in their majority of medial $/ \theta /$ tokens. The Heritage group $(\mathrm{n}=42)$ and English group $(\mathrm{n}=48)$ each produced $[\theta]$ in about $80 \%$ of tokens, while the L1 Dutch/ L2 English group $(n=57)$ produced significantly less $[\theta]$ at a rate of $50 \%$. The next most frequent allophone in the Heritage and English groups was [ð]. While this voicing occurred in 14\% of Heritage tokens and 10\% of English tokens, in both groups [ð] was confined to only two words: "something" (/s $\Lambda \mathrm{m} \theta \mathrm{In} /$ as [s $\Lambda \mathrm{m} \partial \mathrm{In}$ ] or [sımðın]) and "healthy" (/hel $\theta \mathrm{i} /$ as [helði]). The L1 Dutch/ L2 English group produced the voiced variant in only 2 tokens (4\%). The remaining productions by the Heritage and English groups were minimal. The English group realized $/ \theta /$ as $\varnothing(4 \%)$, [t] (2\%), and [s] $2 \%$, while the Heritage group produced $[t](5 \%)$ and [s] (2\%). As in other positions, L1 Dutch/ L2 English group was the most highly variable. The L1 Dutch/ L2 English group's most common realization of $/ \theta /$ was $[\mathrm{s}]$ (18\%), though they also produced [t] (16\%), [d] (5\%), $\varnothing(2 \%)$, and other (4\%).

Word-final $/ \theta /$ production was very similar to the word-medial position. All three groups produced $[\theta]$ in the largest proportion of their productions. Both the Heritage group $(n=116)$ and English group $(n=144)$ produced $[\theta]$ in over $81 \%$ of tokens, while the L1 Dutch/ L2 English group $(n=135)$ produced $[\theta]$ in $42 \%$ of tokens. The English group produced a non- $[\theta]$ variant in only $13 \%$ of tokens. The preferred English group variants were [s] (6\%) and [ð] (4\%). Infrequent English 
group variants included $[\mathrm{t}](2 \%)$ and $\varnothing(1 \%)$. The Heritage group patterned in a similar way, but preferred [ $\mathrm{t}$ ] more heavily, producing it in $12 \%$ of tokens. Other Heritage group variants included [s] (4\%), [ð] (2\%), and $\varnothing$ (1\%). The L1 Dutch/ L2 English group substituted / $/$ / most frequently with $[\mathrm{s}](28 \%)$ and $[\mathrm{t}](22 \%)$, while also using [d] (3\%), $\varnothing(2 \%)$, and other sounds (2\%) more rarely. A summary of the results for both $/ \partial /$ and $/ \theta /$ is shown inTable 5. a log-odds range of $3 . / \theta /$ was similarly strong with a log-odds range of 2.546. The English group consistently produced $[\theta]$ and $[\gamma]$ at rates equal to or higher than the Heritage group. The two groups' productions of $/ \theta /$ were more similar than those of $/ \partial /$, but were still significantly different. The English and Heritage groups' production of /ð/ was most differentiated wordinitially. The English group produced / $/$ / on average $26 \%$ more than the Heritage group at this position (21.9\% mean difference over / $/$ / tokens in all positions).

\begin{tabular}{|c|c|c|c|c|c|c|c|c|c|c|c|c|}
\hline \multirow{3}{*}{$\begin{array}{l} \\
\text { L1 Dutch/ L2 } \\
\text { English }\end{array}$} & \multicolumn{6}{|l|}{ /ð/ } & \multicolumn{6}{|l|}{$\mid \theta /$} \\
\hline & \multicolumn{2}{|c|}{ Initial } & \multicolumn{2}{|c|}{ Medial } & \multicolumn{2}{|c|}{ Final } & \multicolumn{2}{|c|}{ Initial } & \multicolumn{2}{|c|}{ Medial } & \multicolumn{2}{|c|}{ Final } \\
\hline & $\begin{array}{l}{[\mathrm{d}]} \\
{[\partial]} \\
\varnothing \\
{[\theta]} \\
\mathrm{OT} \\
{[\mathrm{t}]}\end{array}$ & $\begin{array}{l}62 \% \\
17 \% \\
17 \% \\
2 \% \\
2 \% \\
1 \%\end{array}$ & $\begin{array}{l}{[\mathrm{d}]} \\
{[\partial]} \\
{[\theta]} \\
{[\mathrm{t}]} \\
\varnothing \\
{[\mathrm{s}]} \\
\text { OT }\end{array}$ & $\begin{array}{l}62 \% \\
17 \% \\
10 \% \\
3 \% \\
3 \% \\
2 \% \\
2 \% \\
\end{array}$ & $\begin{array}{l}{[\theta]} \\
{[\mathrm{d}]} \\
{[\partial]} \\
\mathrm{OT} \\
{[\mathrm{s}]} \\
{[\mathrm{t}]}\end{array}$ & $\begin{array}{l}37 \% \\
23 \% \\
21 \% \\
11 \% \\
9 \% \\
2 \%\end{array}$ & $\begin{array}{l}{[\theta]} \\
{[\mathrm{t}]} \\
{[\mathrm{s}]} \\
{[ð]} \\
{[\mathrm{d}]} \\
\text { OT }\end{array}$ & $\begin{array}{l}53 \% \\
31 \% \\
9 \% \\
3 \% \\
3 \% \\
2 \%\end{array}$ & $\begin{array}{l}{[\theta]} \\
{[\mathrm{t}]} \\
{[\mathrm{s}]} \\
{[\mathrm{d}]} \\
{[ð]} \\
\text { OT } \\
\varnothing\end{array}$ & $\begin{array}{l}50 \% \\
17 \% \\
17 \% \\
8 \% \\
3 \% \\
3 \% \\
2 \% \\
\end{array}$ & $\begin{array}{l}{[\theta]} \\
{[\mathrm{t}]} \\
{[\mathrm{s}]} \\
{[\mathrm{d}]} \\
\text { OT } \\
\varnothing\end{array}$ & $\begin{array}{l}39 \% \\
27 \% \\
26 \% \\
4 \% \\
4 \% \\
2 \%\end{array}$ \\
\hline Heritage & $\begin{array}{l}{[ð]} \\
{[\mathrm{d}]} \\
\varnothing \\
{[\theta]} \\
\mathrm{OT}\end{array}$ & $\begin{array}{l}56 \% \\
23 \% \\
13 \% \\
5 \% \\
1 \%\end{array}$ & $\begin{array}{l}{[ð]} \\
{[\theta]} \\
{[d]} \\
\varnothing\end{array}$ & $\begin{array}{l}68 \% \\
18 \% \\
11 \% \\
2 \%\end{array}$ & $\begin{array}{l}{[ð]} \\
{[\theta]} \\
{[\mathrm{d}]} \\
\text { OT }\end{array}$ & $\begin{array}{l}44 \% \\
30 \% \\
26 \% \\
4 \%\end{array}$ & $\begin{array}{l}{[\theta]} \\
{[\mathrm{s}]} \\
{[\mathrm{t}]} \\
{[ð]}\end{array}$ & $\begin{array}{l}86 \% \\
7 \% \\
5 \% \\
1 \%\end{array}$ & $\begin{array}{l}{[\theta]} \\
{[ð]} \\
{[\mathrm{t}]} \\
{[\mathrm{s}]}\end{array}$ & $\begin{array}{l}79 \% \\
14 \% \\
5 \% \\
2 \%\end{array}$ & $\begin{array}{l}{[\theta]} \\
{[\mathrm{t}]} \\
{[\mathrm{s}]} \\
{[ð]} \\
\varnothing\end{array}$ & $\begin{array}{l}81 \% \\
12 \% \\
4 \% \\
2 \% \\
1 \%\end{array}$ \\
\hline English & $\begin{array}{l}{[ð]} \\
\varnothing \\
{[\theta]} \\
{[\mathrm{d}]}\end{array}$ & $\begin{array}{l}82 \% \\
10 \% \\
5 \% \\
3 \%\end{array}$ & & $\begin{array}{l}79 \% \\
16 \% \\
3 \% \\
2 \%\end{array}$ & $\begin{array}{l}{[\partial]} \\
{[\theta]} \\
{[\mathrm{s}]} \\
{[\mathrm{d}]}\end{array}$ & $\begin{array}{l}48 \% \\
42 \% \\
7 \% \\
3 \%\end{array}$ & $\begin{array}{l}{[\theta]} \\
{[\mathrm{s}]} \\
{[ð]} \\
{[\mathrm{t}]}\end{array}$ & $\begin{array}{l}92 \% \\
6 \% \\
1 \% \\
1 \%\end{array}$ & $\begin{array}{l}{[\theta]} \\
{[ð]} \\
\varnothing \\
{[\mathrm{t}]} \\
{[\mathrm{s}]}\end{array}$ & $\begin{array}{l}81 \% \\
10 \% \\
4 \% \\
2 \% \\
2 \%\end{array}$ & $\begin{array}{l}{[\theta]} \\
{[\mathrm{s}]} \\
{[ð]} \\
{[\mathrm{t}]} \\
\varnothing\end{array}$ & $\begin{array}{l}87 \% \\
6 \% \\
4 \% \\
2 \% \\
1 \%\end{array}$ \\
\hline
\end{tabular}

Table 5: Summary of mean group production of $/ \partial /$ and $/ \theta /$ target tokens for both tasks by position in order of frequency. OT $=$ other

\subsection{Discussion}

The first hypothesis was that the three groups' production of $[\theta]$ and $[ð]$ would differ with the L1 Dutch/ L2 English group producing the lowest rate of $[\theta]$ and $[ð]$, the English monolinguals the highest rate, and the Heritage group producing a relatively high rate that was lower than the English group. This hypothesis was supported. All three groups' productions of $/ \theta /$ and $/ ð /$ were significantly different from one another. Group affiliation was the strongest contributor to both $/ \theta /$ and /ð/ production. /ð/ showed a strong group effect with
$/ \theta /$ production was most differentiated at both the initial and final positions with a mean $6 \%$ difference in production (5.2\% mean difference across all tokens). As predicted, the L1 Dutch/ L2 English group produced significantly less $[\theta]$ and $[ð]$ than both the Heritage or English groups. Overall, the three groups fall along a continuum as predicted. The English and Heritage groups both produced high levels of $[\theta]$ and [ð], with the English group producing more $[\theta]$ and $[ð]$. The L1 Dutch/ L2 English group was highly dissimilar from both of the other groups, and produced significantly less $[\theta]$ and $[\varnothing]$ than either of the other groups.

The effect of word position was also a significant predictor for the production of both $/ \theta /$ and $/ ð /$. While significant, the effect was relatively weak with log-odds ranges of 0.778 for $/ \partial /$ and 0.688 for $/ \theta /$. For 
$/ ð /,[ð]$ production was preferred in the word-medial and word-initial positions and dis-preferred in the word-final position. Lower word-final [ð] production is attested in the literature, as utterance-final voiced fricatives are commonly devoiced in English (Hayes, 2009 , p. 93 ). For $/ \theta /$, $[\theta]$ production was only preferred word-initially, while both word-medial and word-final position weakly dis-preferred $[\theta]$.

The weakest factor in the results was the task effect. Task significantly contributed to /ð/ production, with a relatively weak log-odds range of .556. Unusually, [ð] production was more highly dis-preferred in the reading task, which also showed higher variability in $/ ð /$ production than the more naturalistic picture description task. This is a reversal of the more common sociolinguistic pattern of more standardized and regular production during reading tasks. This could be due to the relative difficulty of producing [ð], combined with the high number of $/ \partial /$ and $/ \theta /$ tokens per utterance in the paragraph (mean of $1.8 / \partial /$ tokens per utterance and $3.6 / \partial /$ and $/ \theta /$ tokens per utterance). This gave the paragraph somewhat of a "tongue-twister" effect that may account for the significant increase in /ð/ production variability on the reading task.

All three groups produced $[\theta]$ at higher rates than $[ð]$, suggesting that $/ \theta /$ may be less marked or easier to produce than $/ \delta /$. This distinction is mostly overlooked in the literature, as the two interdental fricatives are generally treated as a single category (c.f. Flege et al. (1995); Gierut and Storkel (2009); Jekiel (2012)). Where $/ \theta /$ and /ð/ are differentiated, as in Hancin-Bhatt (1994, in Brannen (2011)) and Cutler et al. (2004), it was found that $[\theta]$ was more difficult to discriminate than $[ð]$. The results of Wester et al. (2007) study of Dutch L1 English $/ \theta /$ and $/ ð /$ production correspond with those of the current study - $[\theta]$ was produced at higher rates than $[ð]$. However, Wester et al. did not comment on this differentiation in their study. $/ \theta$ / being less marked than $/ \partial /$ fits with the universal pattern of voiceless obstruents being less marked than their voiced counterparts (Major \& Faudree, 1996).

The second hypothesis was that the allophonic realizations of $/ \theta /$ and $/ ð /$ would differ between the three groups. It was predicted that both the L1 Dutch/
L2 English and the Heritage speakers would realize [t] and [d] at a high rate, while the English group would produce $\varnothing$ and $[s]$ at a higher rate. This hypothesis was partially supported. The groups did show different allophonic inventories for $/ \theta /$ and $/ ð /$. The English group's most commonly realized allophones for $/ \partial /$ were $[\theta]$ and $\varnothing$. Monolingual English allophones for $/ \theta /$ were $[s]$ word-initially and finally and $[ð]$ word-medially. The variable voicing of $/ \theta /$ and $/ \partial /$ has been explained as more dependent on position and part of speech rather than a phonemic voicing difference (Smith, 2013). The Smith (2013) findings were supported in this study because, as mentioned in section 5.2, production of $/ \theta /$ as [ð] was lexically restricted. Heritage speakers generally followed this model of allophone realization, but not at the same rate. The Heritage speakers' patterns of $/ \theta /$ and $/ \partial /$ allophone realization were most dissimilar to English monolinguals at /ð/ in word-initial position, and for $/ \theta /$ in word-final position. These positions showed variation more similar to L1 Dutch/ L2 English speakers than to English L1 speakers. At these positions, the Heritage group frequently produced the alveolar stops [d] and [t] in a way which was similar to the L1 Dutch/ L2 English group and very dissimilar to the English speaker group. Word-initial $/ ð /$, was produced as [d] in $23 \%$ of Heritage tokens and $62 \%$ of L1 Dutch / L2 English tokens, but in only $3 \%$ of English tokens. Word-final $/ \theta /$ was produced as [t] in $12 \%$ of Heritage speaker tokens, while the L1 Dutch /L2 English group produced [ $t$ ] in $26 \%$ of tokens and the English group in only 2\%. These two patterns show that in these two positions, the Heritage group's allophonic realization of /ð/ was very unlike the native speakers of English. The Heritage group was not identical to the L1 Dutch/ L2 English group either. The L1 Dutch/ L2 English group's productions were much more highly variable than the other two groups. Late-learning L1 Dutch/ L2 English speakers exhibited greater variability in all positions, and never produced an allophone more consistently than $62 \%$ of tokens. The L1 Dutch/ L2 English group was also the only group to produce the "others" category sounds [f] and [ts], and the only group to produce "others" 
sounds for both $/ \theta /$ and $/ \delta /$. The only other "others" productions were by the Heritage group: $3 / ð /$ tokens that were produced as $[\mathrm{z}]$.

Except for the cases discussed above (wordinitial/ð/ and word-final $/ \theta /$ ), the allophonic production of the English and Heritage groups were similar. The overall similarity of the Heritage and English groups' $/ \theta /$ and $/ ð /$ allophone production is not surprising, in the context of similar findings of early-acquiring bilinguals such as Chang et al. (2011) and Flege et al. (1995) who found that heritage speaker productions were largely identical to those of the monolingual majority population. However, while similar, the heritage Dutch speakers did maintain significant differences from English monolinguals. This difference was especially clear when comparing the production of word-initial $/ ð /$, and word-final $/ \theta /$, but it was also present in the overall higher variability of Heritage productions and the more frequent production of [d] and [t] variants. Theories of L2 speech acquisition - including the concepts of transfer, lack of contact, and impoverished input - cannot adequately explain the patterns of heritage Dutch speakers' $/ \theta /$ and $/ ð /$ production. Unlike late-learning Dutch bilinguals, heritage Dutch speakers are integrated into Canadian English society and have a native grasp of English. The LEAP-Q results showed that they generally prefer to use English both at home and at work. This, combined with the Heritage speakers' acquisition of English at a young age, means that a lack of contact with L1 English speakers cannot explain the differences between English monolinguals' and Dutch heritage speakers' $/ \theta /$ and /ð/ production patterns. Instead, we propose that variable $/ \theta /$ and $/ \partial /$ production by heritage speakers may be promoted by the effect of ethnic or cultural identity.

Ethnocultural identity has been shown to affect target language (e.g., English) production patterns by Hoffman and Walker (2010). Hoffman and Walker found that an increased orientation to one's ethnic community and identification with the ethnic community correlates with ethnolinguistic variation. Dutch heritage speakers living in Norwich strongly identify themselves with their heritage culture and their $/ \theta /$ and $/ \partial /$ allophone inventories may have been affected by this affiliation. In addition, the in-group insularity promoted by the Calvinist church may play a role by promoting linguistic markers that can identify one as a member of that in-group. This finding would mirror those of Parker (1991) and Huffines (1980) in the Anabaptist Pennsylvania Dutch communities. Because the LEAP-Q is not directed towards religious affiliation or other non-linguistic cultural markers, the question of identity will have to be more directly addressed in future work.

\subsection{Conclusion}

The data presented in this study are a first look at the Dutch-English bilinguals living in Norwich, Ontario and a new insight into heritage speakers' majority language phonology. While heritage speakers generally produce native-like English, their production of $/ \partial /$ and $/ \theta /$ significantly differs from both the majority population of English monolinguals and their parents' generation of late-learning L1 Dutch bilinguals. Heritage speaker speech production falls along a continuum between the "typical" L1 and L2 speakers of English heritage speakers share similarities with both groups (especially monolingual English speakers), but they do not fit completely into either category. The difference between heritage and monolingual English phonology may be understood through the ethnic orientation framework developed by Hoffman and Walker (2010). In order to differentiate themselves from their nonDutch speaking peers, heritage speakers use subtle linguistic cues to mark their speech's Dutch origins, while maintaining intelligibility. This is done primarily through word-initial / $/$ / and word-final $/ \theta /$ production. Intelligibility and native accent are maintained through a monolingual-like high percentage of $[\gamma]$ and $[\theta]$ productions. Dutch ethnic membership can instead be communicated through the careful manipulation of the intrinsically variable monolingual English $/ \partial /$ and $/ \theta /$ allophone inventory. By replacing a portion of English allophones that are typical of monolinguals with those allophones typical of Dutch L1 speakers, Dutch heritage speakers do not compromise their association with either of their Dutch or Canadian identities. 


\section{Notes}

1. Log-odds reflect the difference from a baseline measure of all three groups combined. Positive values reflect that the variable is used at levels higher than baseline, while negative values are lower than baseline. More information about interpreting log-odds can be found in Johnson (2009).

2. Though the census does not separate "Calvinist" from other Christian denominations, over 30\% of Norwich's population identified as "Other Christian" (Statistics Canada, 2013), and Norwich's Netherlands Reformed church (an Orthodox Calvinist denomination) serves approximately 2100 parishioners (Van't Zelfde, 2015).

\section{References}

Balota, D. A., Yap, M. J., Cortese, M. J., Hutchison, K. A., Kessler, B., Loftis, B., Treiman, R. (2007). The English lexicon project. Behavior Research Methods, 39(3), 445-459.

Bernhardt, B., \& Stemberger, J. P. (2002). Intervocalic consonants in the speech of English-speaking Canadian children with phonological disorders. Clinical Linguistics \& Phonetics, 16(3), 199-214. doi:10.1080/02699200110112583

Best, C. T., \& Tyler, M. D. (2007). Nonnative and secondlanguage speech perception: Commonalities and complementarities. In O.-S. Bohn \& M. J. Munro (Eds.), Language experience in second language speech learning: In honor of James Emil Flege (Vol. 17, pp. 1334). Amsterdam, the Netherlands: John Benjamins, B.V.

Blevins, J. (2004). Evolutionary phonology: The emergence of sound patterns. Cambridge;New York;: Cambridge University Press.

Boberg, C. (2010). The English language in Canada: Status, history, and comparative analysis. Cambridge; New York: Cambridge University Press.

Boersma, P. (2013). The use of praat in corpus research Oxford Handbooks Online: Oxford University Press.

Brannen, K. J. (2011). The perception and production of interdental fricatives in second language acquisition. (PhD Dissertation), McGill University, Ann Arbor. Retrieved from digitool.library.mcgill.ca/ thesisfile106279.pdf

Brysbaert, M., \& New, B. (2009). Moving beyond kucera and francis: A critical evaluation of current word frequency norms and the introduction of a new and improved word frequency measure for american english. Behavior Research Methods, 41(4), 977-990. doi:10.3758/BRM.41.4.977
Chang, C. B., Yao, Y., Haynes, E. F., \& Rhodes, R. (2011). Production of phonetic and phonological contrast by heritage speakers of Mandarin. The Journal of the Acoustical Society of America, 129(6), 3964-3980. doi:10.1121/1.3569736

Colantoni, L., \& Steele, J. (2008). Integrating articulatory constraints into models of second language phonological acquisition. Applied Psycholinguistics, 29(03), 489-534. doi:10.1017/S0142716408080223

Crezee, I. (2012). Language shift and host society attitudes: Dutch migrants who arrived in New Zealand between 1950 and 1965. International Journal of Bilingualism, 16(4), 528-540.

Cutler, A., Weber, A., Smits, R., \& Cooper, N. (2004). Patterns of English phoneme confusions by native and non-native listeners. Journal of the Acoustical Society of America, 116(6), 3668-3678. doi:10.1121/1.1810292

Downing, L. (2015). Dutchified English in an Ohio mennonite community. (Master's Thesis), The Ohio State University, Ohio.

Edwards, A. (2010). Dutch english: Tolerable, taboo, or about time too? English Today, 26(1), 19-25. doi:10.1017/S0266078409990563

Flege, J., Munro, M. J., \& MacKay, I. R. A. (1995). Effects of age of second-language learning on the production of english consonants. Speech Communication, 16(1), 1-26. doi:10.1016/0167-6393(94)00044-B

Flege, J. E. (1995). Second language speech learning: Theory, findings, and problems. In W. Strange (Ed.), Speech perception and linguistic experience: Issues in cross-language research (pp. 233-277). Timonium, MD: York Press Inc.

Gatbonton, E., Trofimovich, P., \& Segalowitz, N. (2011). Ethnic group affiliation and patterns of development of a phonological variable. The Modern Language Journal, 95(2), 188-204.

Gierut, J. A., \& Storkel, H. L. (2009). Markedness and the grammar in lexical diffusion of fricatives. Clinical Linguistics \& Phonetics, 16(2), 115-134. doi:10.1080/0269920011011287

Gollan, T. H., Starr, J., \& Ferreira, V. S. (2015). More than use it or lose it: The number-of-speakers effect on heritage language proficiency. Psychonomic bulletin \& review, 22(1), 147-155.

Hancin-Bhatt, B. (1994). Phonological Transfer in Second Language Perception and Production. $\mathrm{PhD}$ Dissertation. University of Illinois at UrbanaChampaign. Retreived from: http://hdl.handle. net/2142/21209 
Hanulikova, A., \& Weber, A. (2012). Sink positive: Linguistic experience with th substitutions influences nonnative word recognition. Attention, Perception, and Psychophysics, 74(3), 613-629. doi:10.3758/s13414011-0259-7

Harrison, B. (2000). Passing on the language: Heritage language diversity in Canada. Canadian Social Trends, 14-19.

Hayes, B. (2009). Introductory phonology. Singapore: Wiley-Blackwell.

Hoffman, M. F., \& Walker, J. A. (2010). Ethnolects and the city: Ethnic orientation and linguistic variation in toronto english. Language Variation and Change, 22(1), 37-67. doi:10.1017/S0954394509990238

Huffines, M. L. (1980). English in contact with Pennsylvania German. The German Quarterly, 53(3), 352-366. doi:10.2307/404912

Hulsen, M. E. H. (2000). Language loss and language processing: Three generations of Dutch migrants in New Zealand (Dissertation). Radboud University Nijmegen, Nijmegan. Retrieved from http://repository.ubn.ru.nl/ handle/2066/18901

Hulsen, H., de Bot, K., \& Weltens, B. (2002). Between two worlds. Social networks, language shift, and language processing in three generations of Dutch migrants in New Zealand International Journal of the Sociology of Language (Vol. 2002, pp. 27).

Jekiel, M. (2012). The evolution of english dental fricatives: Variation and change. (Master's Master's Thesis), The University of Adam Mickiewicz. Retrieved from https://www.academia.edu/7477404/The_evolution_ of_English_dental_fricatives_variation_and_change

Johnson, D. E. (2009). Getting off the goldvarb standard: Introducing rbrul for mixed-effects variable rule analysis. Language and Linguistics Compass, 3(1), 359383. doi:10.1111/j.1749-818x.2008.00108.x

Major, R. C., \& Faudree, M. C. (1996). Markedness universals and the acquisition of voicing contrasts by Korean speakers of English. Studies in Second Language Acquisition, 18(01), 69-90.

Marian, V., Blumenfeld, H. K., \& Kaushanskaya, M. (2007). The language experience and proficiency questionnaire (leap-q): Assessing language profiles in bilinguals and multilinguals. Journal of Speech, Language, and Hearing Research, 50(4), 940-967. doi:10.1044/10924388(2007/067)

Munro, M. J., \& Derwing, T. M. (2006). The functional load principle in esl pronunciation instruction: An exploratory study. System, 34(4), 520-531. doi:10.1016/j.system.2006.09.004
Parameshwaran, M. (2013). Explaining intergenerational variations in English language acquisition and ethnic language attrition. Ethnic and Racial Studies, 37(1), 27 45. doi:10.1080/01419870.2013.827794

Parker, R. (1991). Influences of the Pennsylvania German dialect on the English spoken in" Pennsylvania Dutch country" as a regional identity marker. Term Paper. Hannahs, Napoli.

Rao, R., \& Kuder, E. (2016). Research on heritage spanish phonetics and phonology: Pedagogical and curricular implications. Journal of New Approaches in Educational Research, 5(2), 99-113A. doi:http://dx.doi.org/10.7821/ naer.2016.7.171

Roach, P. (2010). English phonetics and phonology: A practical course (4 ed.). Italy: Cambridge University Press.

Schmid, M., Gilbers, S., \& Nota, A. (2014). Ultimate attainment in late second language acquisition: Phonetic and grammatical challenges in advanced dutch-english bilingualism. Second Language Research, 30(2), 129-157. doi:10.1177/0267658313505314

Schryer, F. J. (1998). The netherlandic presence in ontario: Pillars, class and Dutch ethnicity. Waterloo, ON: Wilfrid Laurier Univ. Press.

Smith, A. B. (2007). General american english speech acquisition. In S. McLeod (Ed.), The international guide to speech acquisition (pp. 128-147). Clifton Park, NY, USA: Thomson Delmar Learning.

Smith, B. (2013). An acoustic analysis of voicing in American English dental fricatives. Ohio State University Working Papers in Linguistics, 60, 117-128.

Statistics Canada. (2012). Census subdivision of Norwich, tp (Ontario) - census 2011. (98-310-XWE2011004). Ottawa, Ontario Retrieved from http://www12.statcan. gc.ca/census-recensement/2011/as-sa/fogs-spg/Factscsd-eng.cfm?LANG=Eng\&GK=CSD\&GC=3532002.

Statistics Canada. (2013). Norwich township, Ontario (code 3532002). (99-004-XWE). Ottawa, Ontario Retrieved from http://www12.statcan.gc.ca/nhs-enm/2011/dp$\mathrm{pd} /$ prof/details/page.cfm?Lang $=\mathrm{E} \& \mathrm{Geo} 1=\mathrm{CSD} \& \mathrm{Cod}$ e1 $=3532002 \&$ Data $=$ Count $\&$ SearchText $=$ Norwich $\&$ Se archType $=$ Begins $\&$ SearchPR $=01 \& \mathrm{~A} 1=\mathrm{All} \& \mathrm{~B} 1=\mathrm{All} \& \mathrm{~T}$ $\mathrm{ABID}=1$.

Van Dijk, J. (1998). Ethnic persistence among DutchCanadian Catholics and Calvinists. Canadian Ethnic Studies/Etudes Ethniques au Canada, 30(2), 23-49.

Van't Zelfde, A. (2015). Norwich (canada). Norwich (Canada) - Gereformeerde Gemeenten. Retrieved from http://gergeminfo.nl/buitenland/gemeenten-amerikacanada/classis-east/norwich-canada 
108 Sarah Cornwell and Yasaman Rafat, English Interdental Fricative Production in Dutch Heritage...

Wester, F., Gilbers, D., \& Lowie, W. (2007). Substitution of dental fricatives in English by Dutch 12 speakers. Language Sciences, 29(2-3), 477-491. doi:10.1016/j. langsci.2006.12.029

Zhao, S. Y. (2010). Stop-like modification of the dental fricative /ð/: An acoustic analysis. The Journal of the Acoustical Society of America, 128(4), 2009-2020. doi:doi:http://dx.doi.org/10.1121/1.3478856.

Recebido em: 31/03/2017

Aceito em: 10/07/2017 
APPENDIX A

\begin{tabular}{|c|c|c|c|c|c|c|}
\hline Group & Age & Gender & $\begin{array}{c}\text { Years of } \\
\text { Education }\end{array}$ & $\begin{array}{l}\text { Age of Im- } \\
\text { migration }\end{array}$ & $\begin{array}{l}\text { Dutch } \\
\text { Fluency }\end{array}$ & $\begin{array}{l}\text { English } \\
\text { Fluency }\end{array}$ \\
\hline \multirow{9}{*}{ Dutch } & 77 & Male & 5 & 14 & 8.5 & 7.5 \\
\hline & 80 & Female & 7 & 21 & 7.5 & 7 \\
\hline & 61 & Male & 9 & 21 & 10 & 10 \\
\hline & 64 & Male & 13 & 23 & 10 & 10 \\
\hline & 27 & Male & 16 & 13 & 10 & 8 \\
\hline & 35 & Male & 12 & 18 & 9 & 8.5 \\
\hline & 44 & Male & 14 & 31 & 10 & 7.5 \\
\hline & 44 & Female & 15 & 31 & 10 & 9 \\
\hline & 81 & Male & 11 & 21 & 10 & 9 \\
\hline \multirow{6}{*}{ English } & 60 & Female & 14 & \multirow{6}{*}{$\mathrm{n} / \mathrm{a}$} & \multirow{6}{*}{$\mathrm{n} / \mathrm{a}$} & \multirow{6}{*}{10} \\
\hline & 60 & Female & 15 & & & \\
\hline & 40 & Female & 18 & & & \\
\hline & 40 & Female & 25 & & & \\
\hline & 41 & Male & 19 & & & \\
\hline & 66 & Male & 14 & & & \\
\hline \multirow{6}{*}{ Heritage } & 28 & Female & 22 & $\mathrm{n} / \mathrm{a}$ & 6.4 & 10 \\
\hline & 31 & Female & 14 & 9 & 9 & 10 \\
\hline & 34 & Male & 14 & 5 & 8 & 10 \\
\hline & 32 & Male & 20 & 6 months & 9.5 & 10 \\
\hline & 58 & Female & 13 & 11 & 3.5 & 10 \\
\hline & 20 & Female & 14 & 5 & 9.5 & 10 \\
\hline
\end{tabular}

Note: Fluency is self-rated from 0 - no knowledge/non-speaker to 10 - native speaker. The fluency ratings presented here are the mean of the speaking and oral comprehension ratings. 


\section{APPENDIX B}

\section{Language Experience and Proficiency Questionnaire (LEAP-Q) Northwestern Bilingualism \& Psycholinguistics Research Laboratory}

Please cite: Marian, Blumenfeld, \& Kaushanskaya (2007). The Language Experience and Proficiency Questionnaire (LEAP-Q): Assessing language profiles in bilinguals and multilinguals. Journal of Speech Language and Hearing Research, 50 (4), 940-967.

\begin{tabular}{|l|l|l|l|l|l|l|l|l|l|}
\hline Age Range & $18-25$ & $26-30$ & $31-35$ & $36-40$ & $41-45$ & $46-50$ & $51-55$ & $56-60$ & $60+$ \\
\hline Gender & Male & Female & other: & & & & & & \\
\hline
\end{tabular}

(1) Please list all the languages you know in order of dominance:

\begin{tabular}{|l|l|l|l|l|}
\hline 1 & 2 & 3 & 4 & 5 \\
\hline
\end{tabular}

(2) Please list all the languages you know in order of acquisition (your native language first):

\begin{tabular}{|l|l|l|l|l|}
\hline 1 & 2 & 3 & 4 & 5 \\
\hline
\end{tabular}

(3) Please list what percentage of the time you are currently and on average exposed to each language.

(Your percentages should add up to $100 \%$ ):

\begin{tabular}{|l|l|l|l|l|l|}
\hline Language: & E.nglish & Dutch & & & \\
\hline L.ist percentage here: & & & & & \\
\hline
\end{tabular}

(4) When choosing to read a text available in all your languages, in what percentage of cases would you choose to read it in each of your languages? Assume that the original was written in another language, which is unknown to you. (Your percentages should add up to 100\%):

\begin{tabular}{|l|l|l|l|l|l|}
\hline Language & English & Dutch & & & \\
\hline L.ist percentage here: & & & & & \\
\hline
\end{tabular}

(5) When choosing a language to speak with a person who is equally fluent in all your languages, what percentage of time would you choose to speak each language? Please report percent of total time.

(Your percentages should add up to 100\%):

\begin{tabular}{|l|l|l|l|l|l|}
\hline Language & English & Dutch & & & \\
\hline L.ist percentage here: & & & & & \\
\hline
\end{tabular}

(6) Please name the cultures with which you identify. On a scale from zero to ten, please rate the extent to which you identify with each culture. (Examples of possible cultures include Canadian, Chinese, Jewish-Orthodox, etc):

\begin{tabular}{|l|l|l|l|l|l|}
\hline List cultures here & & & & & \\
\hline & & & & & \\
\hline
\end{tabular}


(7) How many years of formal education do you have?

Please check your highest education level (or the approximate Canadian equivalent to a degree obtained in another country):

Less than High schoo?

High School

Professional Training
Some Colloge

Coilege

Some Graduate School
Masters

Ph.D.M.D.J.D.

Other:

(8) Age of immigration to Canada, if applicable

\begin{tabular}{|l|l|l|l|l|l|}
\hline Age Range & $0-5$ & $6-10$ & $11-15$ & $16-20$ & $20+$ \\
\hline
\end{tabular}




\section{All questions below refer to your knowledge of DUTCH.}

(1) Age when you...:

\begin{tabular}{|l|l|l|l|}
\hline began acquiring Dutch : & becane fluent in Dutch: & began reading Dutch: & became fuent reading in Dutch: \\
\hline & & & \\
\hline
\end{tabular}

(2) Please list the number of years and months you spent in each language environment:

\begin{tabular}{|l|l|l|}
\hline & Years & Months \\
\hline A country where Dutch is spoken & & \\
\hline A family where Dutch is spoken & & \\
\hline A school andior working environment where Dutch is spoken & & \\
\hline
\end{tabular}

(3) On a scale from zero to ten, with ten being more proficient, please select your level of proficiency in speaking, understanding, and reading Dutch:

\begin{tabular}{|l|l|l|l|l|l|}
\hline Speaking & Understanding spoken language & Reading & \\
\hline
\end{tabular}

(4) On a scale from zero to ten, with ten being most contributing, please select how much the following factors contributed to you learning Dutch :

\begin{tabular}{|l|l|l|l|}
\hline Interacting with fricnds & & Languge capes sele instruction & \\
\hline Interacting with family & & Watching TV & \\
\hline Reading & & Lisconing to the radio & \\
\hline
\end{tabular}

(5) Please rate to what extent you are currently exposed to Dutch in the following contexts:

\begin{tabular}{|l|l|l|l|}
\hline Interacting with fricnds & & Listoning wadimusic & \\
\hline Interacting with family & & Resding & \\
\hline Watching TV & Self-instruction & \\
\hline
\end{tabular}

(6) In your perception, how much of a foreign accent do you have in Dutch?

(7) How frequently do others identify you as a non-native speaker based on your accent in Dutch: 


\section{All questions below refer to your knowledge of ENGLISH.}

(1) Age when you...:

\begin{tabular}{|l|l|l|l|}
\hline began acquiring Enghish: & became fluent in English: & began reading English: & became fluent reading in English: \\
\hline & & & \\
\hline
\end{tabular}

(2) Please list the number of years and months you spent in each language environment:

\begin{tabular}{|l|l|l|}
\hline & Years & Months \\
\hline A country where English is spoken & & \\
\hline A family where English is spoken & & \\
\hline A school and/or working environment where English is spoken & & \\
\hline
\end{tabular}

(3) On a scale from zero to ten, with ten being more proficient, please select your level of proficiency in speaking, understanding, and reading English:

\begin{tabular}{|l|l|l|l|l|l|}
\hline Speaking & $\begin{array}{l}\text { Understanding spoken } \\
\text { language }\end{array}$ & & Reading & \\
\hline
\end{tabular}

(4) On a scale from zero to ten, with ten being most contributing, please select how much the following factors contributed to you learning English :

\begin{tabular}{|c|c|}
\hline Interucting with friends & Language tupeselé antruetion \\
\hline Interacting with family & Watching TY \\
\hline Reading & Listening to the radio \\
\hline
\end{tabular}

(5) Please rate to what extent you are currently exposed to English in the following contexts:

\begin{tabular}{|l|l|l|l|}
\hline Interacting with friends & & Listening to radiwimusic & \\
\hline Interacting with family & & Reading & \\
\hline Watching TV & & Self-instruction & \\
\hline
\end{tabular}

(6) In your perception, how much of a foreign accent do you have in English?

(7) How frequently do others identify you as a non-native speaker based on your accent in English: 


\section{APPENDIX C}

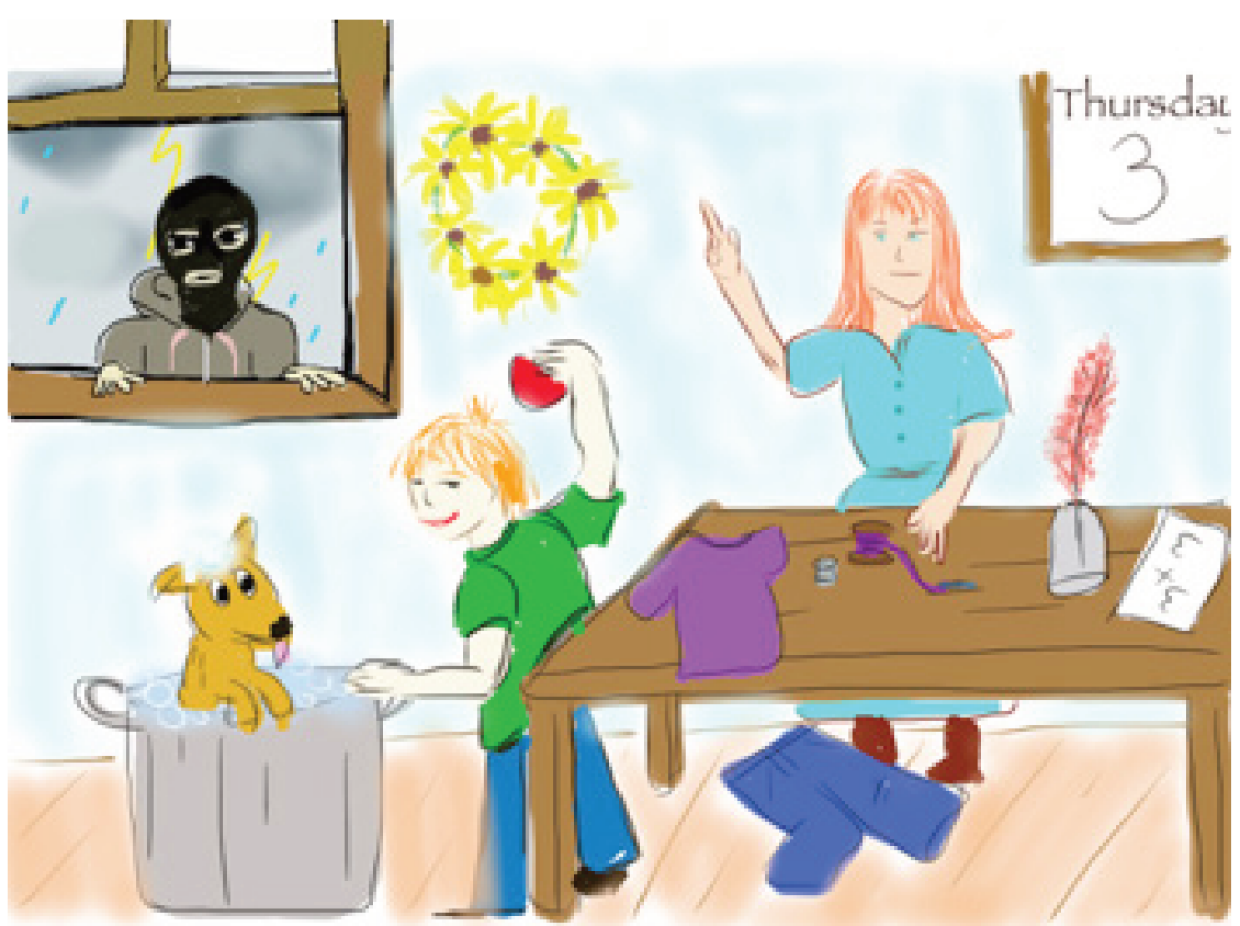

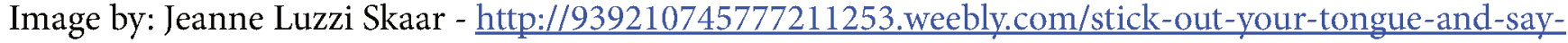
$\underline{\text { th.html }}$

Image used with permission

\begin{tabular}{|l|l|l|l|}
\hline & Initial & Medial & Final \\
\hline$/$ / & $\begin{array}{l}\text { the } \\
\text { they } \\
\text { them } \\
\text { those } \\
\text { this } \\
\text { that }\end{array}$ & $\begin{array}{l}\text { mother } \\
\text { brother } \\
\text { another } \\
\text { feather } \\
\text { weather } \\
\text { lather } \\
\text { bathing } \\
\text { clothes }\end{array}$ & bathe \\
\hline$/ \theta /$ & $\begin{array}{l}\text { thunderstorm } \\
\text { thief } \\
\text { throw } \\
\text { Thursday } \\
\text { bathb } \\
\text { third } \\
\text { three } \\
\text { thread } \\
\text { thimble }\end{array}$ & $\begin{array}{l}\text { bath } \\
\text { math } \\
\text { wreath } \\
\text { underneath } \\
\text { both } \\
\text { with }\end{array}$ \\
\hline
\end{tabular}




\section{APPENDIX D}

Please review the following paragraph. When you are ready, read it aloud into the microphone.

Ruth sighs and looks at the clock. It is almost three-thirty, and at three-thirty, she will bathe her two dogs: Thor and Zeus. The weather had been bad on Thursday: it rained heavily and even thundered a bit. Still, Ruth had taken them to the park and thrown the ball for them. The dogs are very muddy, but they both loathe the bathtub. Ruth decides that Thor will go first, and she tries to soothe him as she drags him towards the bath. The other dog waits impatiently in the kennel. Ruth takes a deep breath, and pushes Thor into the water. Though he was seething and angry a second ago, now Thor seems to enjoy the water, and he bites it playfully with his teeth. Ruth takes the shampoo and works up a lather in his fur, getting soap everywhere. She can breathe more easily now. She washes the shampoo out and brushes Thor's fur smooth again. "These dogs are not so difficult - I can do this!", she thinks. When Thor is clean, Ruth brushes his teeth too, to keep him healthy. She has special toothpaste and a toothbrush that are made for dogs. Thor and Zeus are two lucky dogs! They are clean, and now their bathing is done. 